\title{
Spray dried pre-quarg from over acidified milk and whey UF retentates
}

\author{
by \\ J. KOROLCZUK * and Dorota GRZELAK **
}

\section{S u $\mathrm{m}$ m a ry}

UF retentates from skim milk concentrated up to 5 times and whey concentrated up to 10 times, pasteurized at $65^{\circ} \mathrm{C}$ for $20 \mathrm{~min}$., were inoculated with $5 \%$ Lactobacillus acidophilus starter and acidified for 24 hours to $\mathrm{pH} 3.5-3.8$, then they were repasteurized and spray dried. Acidified milk or whey UF retentates powders contained $94-96 \%$ dry matter $45-65 \%$ protein, $6.2-7.8 \%$ ashes, $13-15 \%$ lactic acid, $19-23 \%$ lactose and $\mathrm{pH}$ of $10 \%$ water solution was 3.8-4.0.

Acidified and non-acidified milk and whey UF retentates powders had a total bacterial count (c.f.u.) of $4.2 \times 10^{4}$ to $5.5 . \times 10^{5}$ per gram. The mould count was $1-10^{2} / \mathrm{g}$ and yeasts $1-10 / \mathrm{g}$. There was less than 10 Coliforms and Enterococci per gram.

Reconstituted quargs obtained by mixing acidified and nonacidified milk or milk and whey UF retentates powders with liquid skim milk or fermented milk were characterized by a total bacterial count (c.f.u.) of $4 \times 10^{7}$ to $1 \times 10^{10} / \mathrm{g}$, moulds from 1 to $2 \times 10^{1} / \mathrm{g}$ and yeasts from 1 to $5 \times 10 / \mathrm{g}$. During 21 days of storage of reconstituted quargs at $6+2^{\circ} \mathrm{C}$ Coliforms and Enterococci were absent in $1.0 \mathrm{~g}$, in some samples moulds number increased up to $2 \times 10^{4}$ and yeasts number up to $3 \times 10^{3}$. Total bacterial count was practically constant during three weeks of storage at $6^{\circ} \mathrm{C}$.

Organoleptic quality of thus obtained quargs was good and no major changes were observed during 3 weeks of storage.

Key words:

Quarg, L. acidophilus, ultrafiltration, acidified whey retentate powder, acidified milk retentate powder.

Abbreviated title

Spray dried quarg.

* Till 30 septembre 1984: Laboratoire de Recherches de Technologie Laitière (INRA), 65, rue de Saint-Brieuc, 35042 Rennes Cedex.

** Institute of Dairy Industry, 66/68 Hoza Str., 00-682 Warsaw, Poland. 


\section{Rés u m é}

Des rétentats d'ultrafiltration de lait écrémé concentré jusqu'à 5 fois et de lactosérum concentré jusqu'à 10 fois, chauffés à $65^{\circ} \mathrm{C}$ pendant $20 \mathrm{~min}$, étaient inoculés avec $5 \%$ de levain de Lactobacillus acidophilus et acidifiés à $43^{\circ} \mathrm{C}$ pendant $24 \mathrm{~h}$ jusqu'à $p H \quad 3,5-3,8$, ils étaient chauffés à nouveau à $65^{\circ} \mathrm{C}$ pendant 20 minutes et séchés par atomisation.

Les poudres des rétentats du lait ou du lactosérum avaient une teneur égale à $94-96 \%$ en matière sèche, $45-65 \%$ en protéines, 6,2-7,8\% en cendres, $13-15 \%$ en acide lactique, $19-23 \%$ en lactose et le $\mathrm{pH}$ des solutions à $10 \%$ était de 3,8 à 4 .

Les poudres de rétentats de laits acidifiés et non-acidifiés avaient une flore totale mésophile de $4,2 \times 10^{4}$ à $5,5 \times 10^{5} / \mathrm{g} ; 1-100$ moisissures $/ g$ et $1-10$ levures $/ g$. Le nombre de Coliformes et Enterocoques était inférieur à 10 par gramme.

Les fromages de type quarg étaient obtenus par mélange des poudres de rétentats de laits et de lactosérum acidifiés ou non-acidifiés avec du lait frais ou acidifié. Ces fromages avaient une flore totale mésophile de l'ordre de $4 \times 10^{7}$ à $1 \times 10^{10} / \mathrm{g} ; 1-20$ moisissures $/ \mathrm{g}$ et $10-100$ levures/g. Après 21 jours de conservation de fromages reconstitués à $6 \pm 2{ }^{\circ} \mathrm{C}$ le nombre de Coliformes et Entérocoques était inférieur de $10 / \mathrm{g}$; le nombre de moisissures augmentait dans certains échantillons jusqu'à $2 \times 10^{4} / \mathrm{g}$ et celui de levures jusqu'à $3 \times 10^{3} / \mathrm{g}$. La flore totale mésophile était pratiquement constante pendant trois semaines de stockage à $6^{\circ} \mathrm{C}$. La qualité organoleptique des fromages était bonne et aucun changement n'était observé pendant 3 semaines de stockage.

Mots clés:

Fromage Quarg, L. acidophilus, ultrafiltration, retentat acidifié de lactosérum en poudre, rétentat acidifié de lait en poudre.

Titre abrégé :

Fromage Quarg en poudre.

\section{INTRODUCTION}

Acid curd cheese obtained from milk retentate as described by Maubois and others (Maubois et al., 1969; Maubois and Mocquot, 1971; Brulé et al., 1974; Maubois and Mahaut, 1974; Brulé et al., 1975; Maubois and Mocquot, 1975; Covacevich and Kosikowski, 1977; Puhan and Gallmann, 1981; Gungerich, 1981) is characterised by a higher content of whey proteins and calcium, as compared to the traditional product. Higher retention of whey proteins and calcium increases the nutritional value of acid curd cheese, but sometimes acid taste (Brulé et al., 
1975) and gelatin-like texture (Covacevich and Kosikowski, 1978a) were detected. If before ultrafiltration the $\mathrm{pH}$ of milk is either slightly decreased (Brulé et al., 1974; Friis, 1981; Puhan and Gallmann, 1981) or markedly lowered to 4.5-4.7 (Stenne, 1973; Mahaut et al., 1982) the retention of calcium decreases and quarg texture becomes typical as in traditional technology.

Spray dried milk retentates (Maubois and Mocquot, 1975) and milk retentates acidified to $\mathrm{pH} 4.6$ before drying (Ehsani et al., 1982) makes it possible to prepare a long lasting semi-product from which one can prepare the fresh acid cheese, at home or in a dairy factory.

To increase dry matter and protein content in the UF milk retentates while making Mozzarella and Cheddar cheese Covacevich and Kosikowski (1978b) used freeze-dried UF retentate powder. To acidify UF retentates Ehsani et al. (1982) used lactic acid. For the same purpose we used over-acidified milk i.e. milk brought to $\mathrm{pH}$ 3.53.8 by Lactobacillus acidophilus (Korolczuk et al., 1983) or acidified to $\mathrm{pH}$ 3.6-3.8 UF milk and whey retentates by Lactobacillus acidophilus (Korolczuk and Grzelak, 1984).

As over-acidification, below the isoelectric point of casein gives the opportunity to pasteurize the acidified milk of UF retentates and to spray-dry them at normal temperatures instead of keeping them at $0^{\circ} \mathrm{C}$ before drying. We used this method to prepare over-acidified UF milk and whey retentates powders to be used as acidifying agent in quarg type cheese technology.

\section{MATERIALS AND METHODS}

Pooled skim milk and skimmed sweet rennet whey were heat treated at $65^{\circ} \mathrm{C}$ for 20 minutes, then cooled to $50-53^{\circ} \mathrm{C}$ and ultrafiltrated to reach concentration up to 5 times for the milk and up to 10 times for the whey (Fig. 1). A hollow-fiber type UF module $\left(3 \times 0.9 \mathrm{~m}^{2}\right)$ equipped with PM 50 membranes (Amicon, U.S.A.) was used. The conditions of ultrafiltration were as follows: inlet/outlet pressure was 2.0-1.8 bar/1.0-0.8 bar, recirculation rate was $2 \mathrm{~m}^{3} / \mathrm{h}$, temperature $53 \pm 2^{\circ} \mathrm{C}$. Ultrafiltration rate at the beginning of the process was about $40-60 \mathrm{l} / \mathrm{m}^{2} . \mathrm{h}$ and at the end about $10 \mathrm{l} / \mathrm{m}^{2} . \mathrm{h}$. Heat treated $\left(65^{\circ} \mathrm{C} ; 20 \mathrm{~min}\right.$.) retentates were inoculated with $5 \%$ starter of L. acidophilus $1 \mathrm{~T}$ (from the collection of the Agricultural University in Warsaw). The starter was prepared one day before, on skim milk heated at $95^{\circ} \mathrm{C}$ for $30 \mathrm{~min}$, fermented to $\mathrm{pH} 4.5-4.3$ at $43^{\circ} \mathrm{C}$ and stored overnight at $5^{\circ} \mathrm{C}$. Acidification of retentates lasted for 18-24 hours at $43 \pm 2^{\circ} \mathrm{C}$. Acidified to $\mathrm{pH} 3.5-3.8$ retentates were heat treated $\left(65^{\circ} \mathrm{C}, 20 \mathrm{~min}\right.$.) and spray dried (Niro-Atomizer, Denmark) with inlet/ outlet air temperatures $180-170^{\circ} \mathrm{C} / 90-60^{\circ} \mathrm{C}$. Spray dried, non-acidified milk retentates were prepared by the same procedure but without 


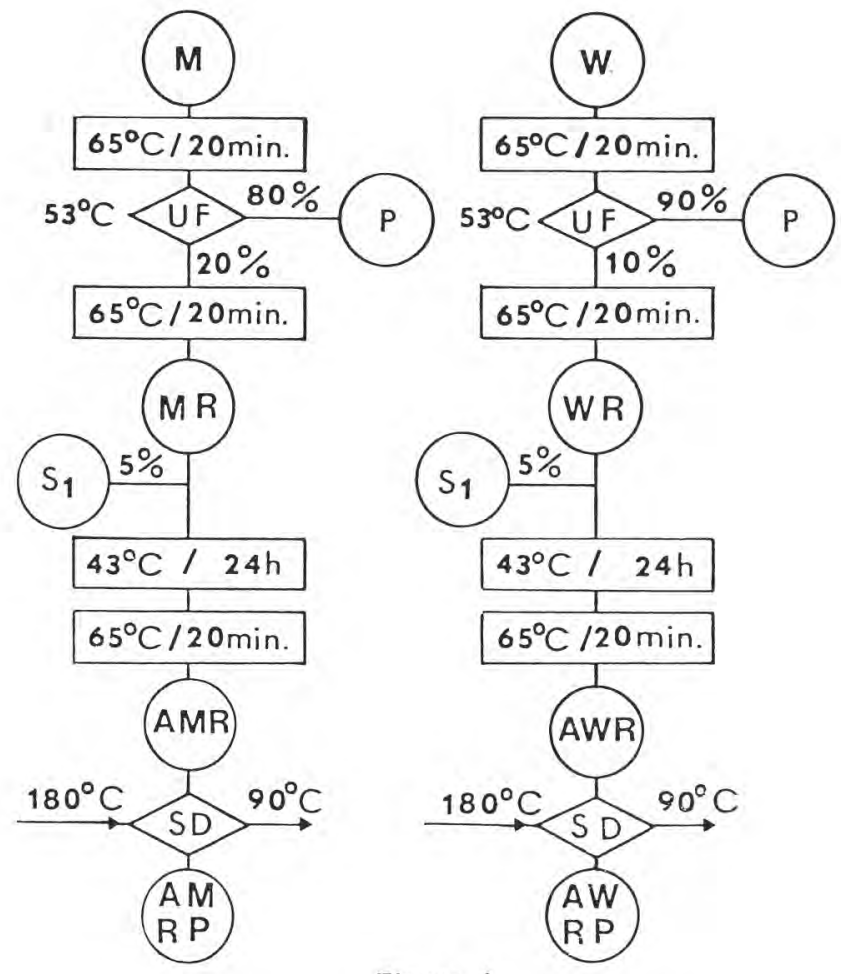

Figure 1

Diagram of preparation of acidified milk and whey retentate powders: M-milk, $W$-whey, UF-ultrafiltration, P-permeate, MR-milk retentate, WR-whey retentate, $S_{\text {, }}$-L. acidophilus starter, AMR-acidified milk retentate, AWR-acidified whey retentate, SD-spray drying, AMRP-acidified milk retentate powder, AWRP-acidified whey retentate powder.

\section{Figure 1}

Schéma du procédé de préparation des rétentats acidifiés de lait écrémé et de lactosérum en poudre: M-lait, W-lactosérum, UF-ultrafiltration, P-perméat, MR-rétentat de lait, WR-rétentat de lactosérum, $\mathrm{S}_{1}$-levain de L. acidophilus, AMR-rétentat acidifié du lait, AWR-rétentat acidifié de lactosérum, SD-séchage spray, AMRP-rétentat acidifié de lait en poudre, AWRP-rétentat acidifié de lait en poudre, AWRP-rétentat acidifié de lactosérum en poudre.

acidification. The powders were sealed in multilayer, aluminium foil bags and kept at room temperature for up to 6 months before using them for the preparation of quarg type cheeses.

Reconstituted quarg samples were prepared on a laboratory scale (10 kg each) by mixing fresh heat treated skim milk (Fig. 2 a) or fermented skim milk (Fig. $2 \mathrm{~b}$ ) with powders of milk retentate (MRP), acidified milk retentate (AMRP) or acidified whey retentate (AWRP). In the case of fresh pasteurized milk used as a solvent, 


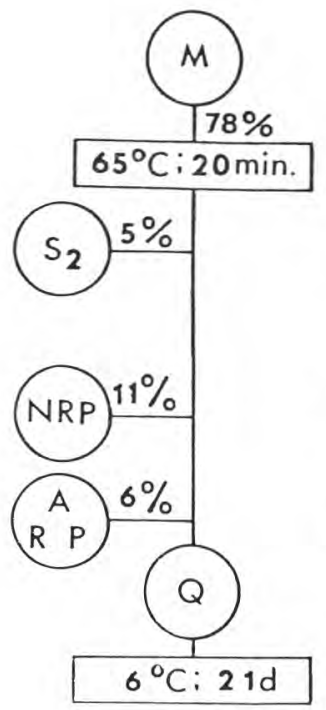

a

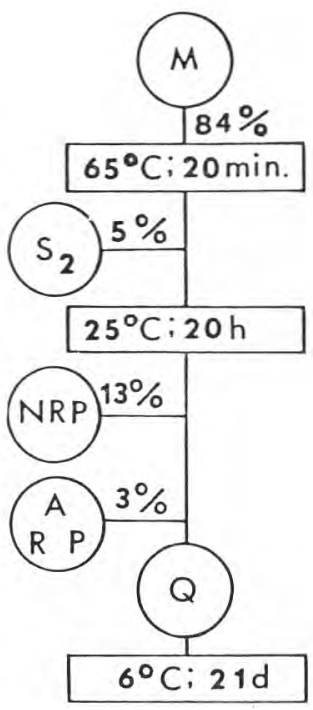

$b$

Figure 2

Diagram of preparation of regenerated quargs $(Q)$ from milk $(M)$, butter starter $\left(S_{2}\right)$, neutral milk retentate powder (NRP) and acidified milk or whey retentate powder $(A R P)$.

Figure 2

Schéma du procédé de préparation de fromage frais type quarg reconstitué (Q) à partir de : M-lait; $\mathrm{S}_{2}$-ferment à beurre, NRP-rétentat neutre de lait en poudre ; ARP-rétentat acidifié du lait ou de lactosérum en poudre.

$5 \%$ of commercial butter starter (WCK, Poland) was added to increase the number of viable lactic acid bacteria and to develop the flavour. The starter was a composition of Str. Lactis, Str. cremoris and Str. diacetylactis. The proportions of ingredients were calculated as to obtain a protein concentration in the final product equal to or higher than $12.5 \%$ characteristic for normal quargs and a lactic acid content of about 1.4-1.2\% equivalent to $\mathrm{pH}$ 4.8-4.6.

Reconstituted quarg samples, closed in glass jars (250 g each) were kept for 21 days at $6 \pm 2^{\circ} \mathrm{C}$.

The $\mathrm{pH}$ of retentates and quargs was determined by means of a pH-meter type PHM-64 (Radiometer, Denmark). The titrable acidity was determined by using a titrator type TTT-60 (Radiometer, Denmark) and expressed in percentage of lactic acid. Nitrogen was determined by Kjeldahl method using a Kjel-Foss Automatic apparatus (A/S N. Foss Electric, Denmark). Moisture content was determined at $102^{\circ} \mathrm{C}$ for 5 hours and ash at $550^{\circ} \mathrm{C}$ (AOAC, 1975), lactose by the method of FIL-IDF (1974 a). Microbiological analysis 
and sensory evaluation were carried out using standard methods (FIL-IDF, 1971a, b; 1974b ; 1980; 1981a).

\section{RESULTS AND DISCUSSION}

Drying process milk retentates acidified to $\mathrm{pH} 3.6-3.8$ caused some browning when outlet temperatures were about $80-90^{\circ} \mathrm{C}$ and the powder left in a cyclon for over half an hour. The reduction of outlet temperature to $60-65^{\circ} \mathrm{C}$ by introduction of room temperature air at the bottom of the drier solved this problem. This system is commonly used in the industrial scale driers, so it would cause no problems when scaling up the process.

Powders obtained from UF whey or milk retentates or from acidified retentates contained $94-96 \%$ dry matter (Fig. 3), $65 \%$

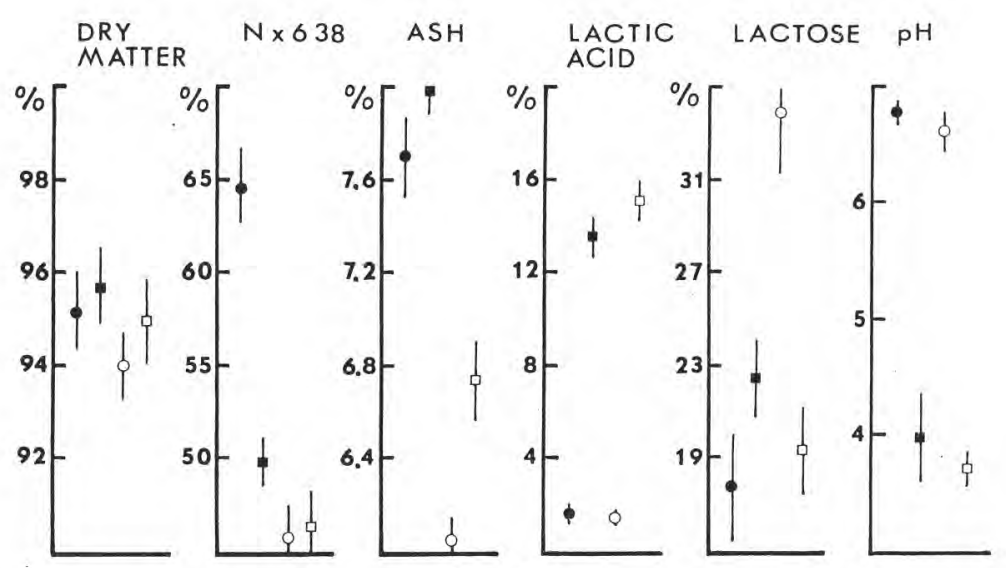

Figure 3

Chemical composition of: - milk retentate powder, $\mathbf{m}$ acidified milk retentate powder, 0 whey retentate powder, $\square$ acidified whey retentate powder.

Figure 3

Composition chimique des poudres de: rétentat de lait; a rétentat acidifié de lait ; O rétenta de lactosérum ; 口 rétentat de lactosérum acidifié.

protein in the case of milk retentate and about $46-50 \%$ protein in the case of whey, acidified whey and acidified milk retentates powders. Lactic acid concentration in the AMRP or AWRP was about 13-15\%. In some samples lactic acid content was over $20 \%$, but in this case the powder sticked too much to the dryers walls and formed a cakelike layer. Lactose concentration was of the level of $18-23 \%$ for 
MRP, AMRP and AWRP and about $33 \%$ for neutral whey retentate powder (WRP). Ash content was about 7.6-8\% for milk and 6-6.8\% for whey retentate powders. As about $80 \%$ of calcium is retained by casein, so the milk retentates were rich in minerals. The $\mathrm{pH}$ of $10 \%$ water solutions of acidified retentates was about 3.8-4.0 which was about $0.2 \mathrm{pH}$ units higher than the $\mathrm{pH}$ of acidified retentates before drying. This was probably cased by some losses of lactic acid during the process, and by the dilution effect, as the retentates before drying contained $15-18 \%$ dry matter.

By mixing milk (Fig. 2 a) or fermented milk (Fig. 2 b) with neutral milk retentate powder and acidified milk or whey retentate powder, we obtained four types of quargs. They contained 23-24\% dry matter, $12-13 \%$ protein, 1.7-2.2 \% ashes and 1.1-1.4\% of titrable lactic acid (Fig. 4). The protein content was typical to traditional
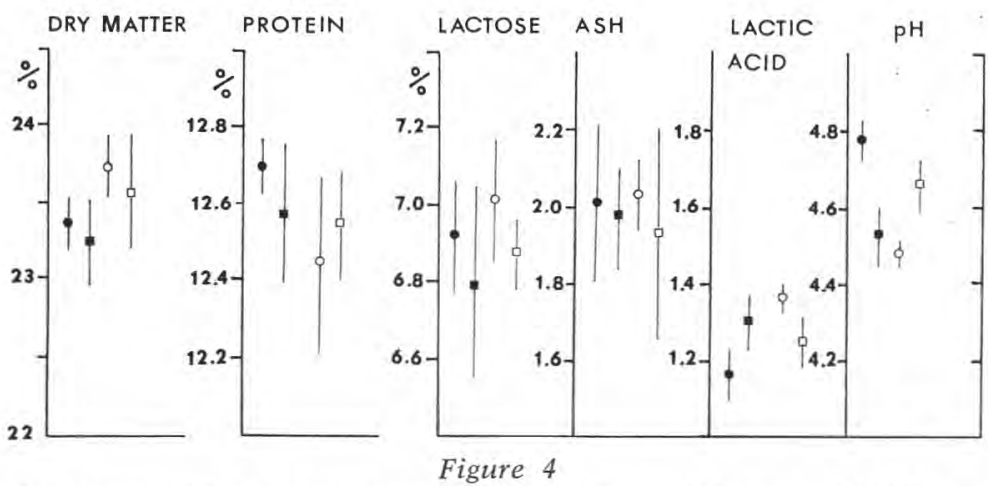

Chemical composition of regenerated quargs obtained from: milk $(M)$, neutral milk retentate powder (NRP) and acidified milk retentate powder $(A M R P) \bullet$; fermented milk (FM), NRP and AMRP 둘 $M, N R P$ and AWRP O;FM, NRP and $A W R P$

\section{Figure 4}

Composition chimique des fromages frais type quarg (reconstitué) obtenu à partir de: - lait $(M)$, poudre de rétentat de lait (NRP) et poudre de rétentat acidifié de lait (AMRP); a lait fermenté (FM), NRP et AMRP; $\odot$ M, NRP et AWRP ; $\square$ FM, NRP et AWRP.

quargs, but the dry matter was about 6-7 \% higher because of higher lactose and minerals content. It is possible to reduce dry matter to a level of about $17.5 \%$ characteristic for traditional quarg but diafiltration has to be used in this case to decrease lactose content in milk and whey protein retentates. But as practically it does not make sense, we renounced this idea for the moment.

As indicated in fig. 2 and 3 about $83-89 \%$ of the final product total mass was coming from liquid milk or fermented milk. But, 

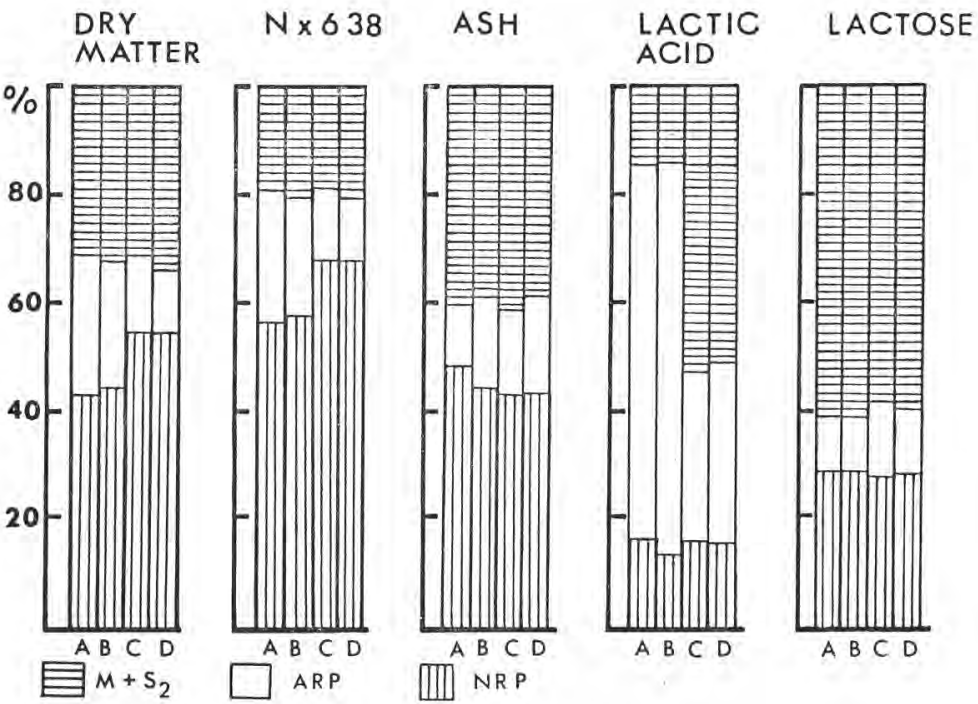

Figure 5

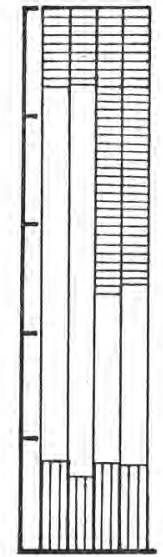

A B C D

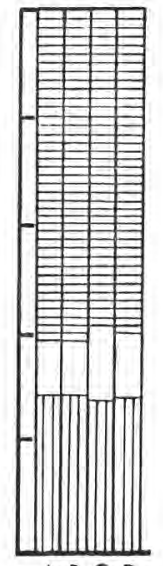

$A B C D$

Origin of basic components of regenerated quargs: $M+S_{2}$, milk + starter or fermented milk; NRP, neutral milk retentate powder; $A R P$, acidic milk or whey retentate powder. Samples: $A=$ milk $(M)+$ neutral milk retentate powder $(N R P)+$ acidified milk retentate powder $(A M R P) ; B=M+N R P$ + acidified whey retentate powder $(A W R P) ; C=$ fermented milk $(F M)+N R P$ $+A M R P ; D=F M+N R P+A W R P$.

Figure 5

Origine des principaux composants du fromage frais type quarg (régénéré): $\mathrm{M}+\mathrm{S}_{2}$, lait + ferment à beurre ou lait fermenté ; NRP, rétentat de lait en poudre ; ARP, rétentat acidifié de lait ou de lactosérum en poudre. Echantillons : $\mathrm{A}=$ lait $(\mathrm{M})$ + rétentat neutre de lait en poudre (NRP) + rétentat acidifié de lait en poudre (AMRP); $B=M+N R P+$ rétentat acidifié de lactosérum en poudre $($ AWRP $) ; C=$ lait fermenté $(F M)+N R P+A M R P ; D=F M+N R P$ + AWRP.

if taking into account the dry matter balance (Fig. 5), 44-54\% comes from the neutral milk retentate powder and $12-24 \%$ from acid milk or acid whey retentate powder. About 56-68\% protein comes from neutral and $12-24 \%$ from acid retentates powders. Over $70 \%$ of lactic acid comes from acid retentates if quarg was produced from milk and about $30 \%$ if fermented milk was used. About $44-48 \%$ of the minerals originate from milk retentate and another $41-44 \%$ comes from normal milk. Sixty to $62 \%$ of lactose originated from liquid milk or fermented milk. As over $2 / 3$ of dry matter and over $3 / 4$ of the protein originated from dried neutral and acid UF retentates, the quarg produced by this method could be a good solution for seasonal variations of milk suply and for reduction of transport costs. As about $95 \%$ of milk protein are retained by UF and no 
fines are lost in the whey, the proposed method combines the advantages of traditional technology and MMV method (Maubois, Mocquot and Vassal, 1969).

Whey proteins, which represent a higher nutritional value than casein, are almost absent in traditional quargs. If quarg is produced by MMV method (Maubois, Mocquot and Vassal, 1969) the whey protein content increase to about $15-20 \%$ of total protein. When acidified whey retentate powder is used as a source of lactic acid, the level of whey protein could be about $30-40 \%$ of total protein depending if milk or fermented milk is used as a solvent.

Organoleptic quality of quargs was good and no detectable changes were observed during a 3 weeks storage period at $6^{\circ} \mathrm{C}$. In some samples obtained from acidified milk retentate we observed sometimes a sandy texture. It might have been caused by poor solubility of dried acid casein. No such phenomena was observed in the quargs prepared from acidified whey retentate powder. This could be explained by the fact, that denaturation of whey protein in acidic solutions is rather low (Harwalkar, 1980) and we did not heat whey retentate at high temperature. The texture of quargs obtained from milk and acidified whey retentate, which contained around $40 \%$ of whey proteins, was much softer than that of pure milk quargs, but no whey expulsions was observed during storage, which indicates good water binding capacity of whey proteins.

Total bacterial count of spray dried retentates was of the order of $10^{5}$ C.F.U./g and about $10^{4}$ C.F.U./g for acidified retentates. Moulds number of neutral retentates was on the level of $10-100$ and less than $1 / \mathrm{g}$ for acidified retentates (Fig. 6). The yeasts number was lower than $10^{1} / \mathrm{g}$ and again lower for acidified than neutral retentates powders. Coliform and Enterococci were absent in $0.1 \mathrm{~g}$, though it happened to detect them in some samples of neutral whey retentates being present in $0.1 \mathrm{~g}$ but absent in $0.01 \mathrm{~g}$. Lower contamination of acidified retentates resulted from the combined action of temperature and acidity. Acidified retentates, after fermentation contained about $10^{9}$ lactic acid bacteria (C.F.U.)/g while after heat treatment and drying about $10^{4}$ lactic acid bacteria (C.F.U.)/g. It confirms that at low $\mathrm{pH}$ even low temperature long time heat treatment is sufficient to reduce the number of living bacteria by the factor of $10^{5}-10^{6}$.

Regenerated quargs were characterised by the total bacterial count in the range $4 \times 10^{7}-4 \times 10^{10}$ (table 1$)$. The higher number was observed, as could be expected in the quargs made from fermented milk. During three weeks of storage at $6^{\circ} \mathrm{C}$ the number of viable bacteria in some samples increased by about one log, in others it remained constants. Moulds number after one day was about $1-10 / \mathrm{g}$ and remained unchanged in most samples. In the samples prepared from the milk and acidified milk retentate powder we observed an increase of moulds number up to about $2 \times 10^{4} / \mathrm{g}$, but the initial number in these samples was about 10 times higher than in other 


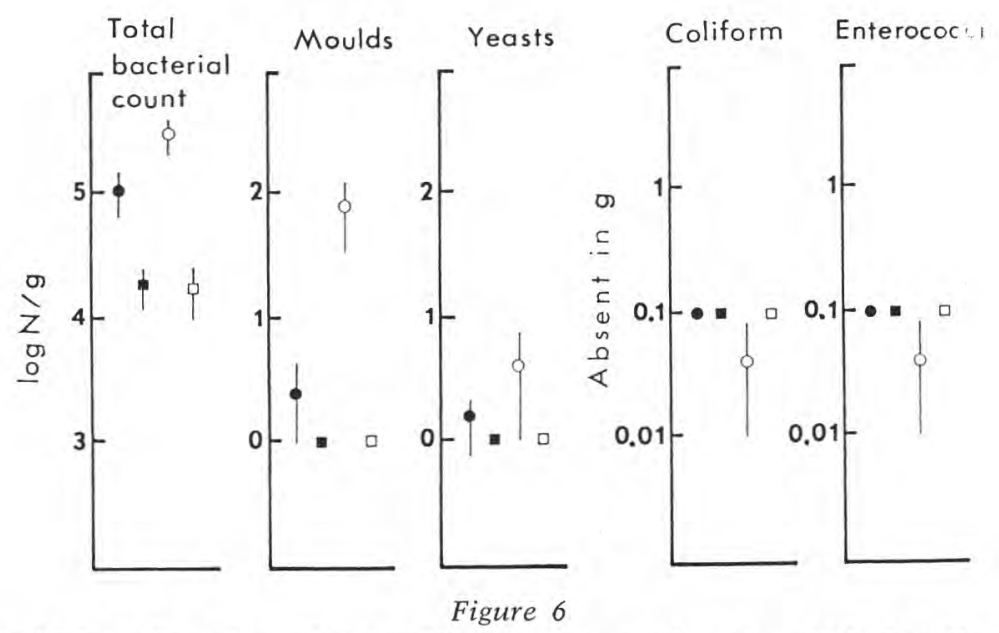

Microbiological quality of: - milk retentate powder; acidified milk retentate powder; 0 whey retentate powder; $\square$ acidified whey retentate powder.

Figure 6

Qualité microbiologique de poudres obtenues à partir de: • rétentat de lait; - rétentat acidifié de lait; $O$ rétentat de lactosérum; $\square$ rétentat acidifié de lactosérum.

ones. The yeasts number was about $1-10 / \mathrm{g}$ and in some samples increased up to $10^{3} / \mathrm{g}$ while in others it remained unchanged during 3 weeks of storage at $6^{\circ} \mathrm{C}$. Enterococci and Coliforms were absent in all samples during 3 weeks of storage.

The regenerated quargs obtained by the method described here, especially ones prepared by dissolving retentates powders in the fermented milk where characterised by the high level of viable bacteria $\left(10^{9}-10^{10}\right.$ C.F.U./g) characteristic for traditional quargs, but at the same time they were not contaminated by Coliforms and Enterococci. As viable lactic acid bacteria may represent an important value from the nutritional point of view, the preparation of quargs by dissolving the powders of acidified and neutral milk and whey retentates in the fermented milk could be recommended.

In this case, the process lasts as long as the traditional one, and special precautions have to be taken to avoid reinfection. But even in this case if comparing with the traditional process the volume of fermentation vats is reduced five times, as the milk and starter volume per $\mathrm{kg}$ of quarg is reduced from 4.5-4.6 1 to $0.8-0.9 \mathrm{l}$. If the process follows the procedure shown in fig. 2 only $5 \%$ of butter starter is needed and the flavour rich starter is recommended. In this case however the flavour only develops the next day, and the 


\section{TABLE 1}

Microbiological quality of regenerated quargs after 1,10 and 21 days of storage at $6 \pm 2^{\circ} \mathrm{C}$

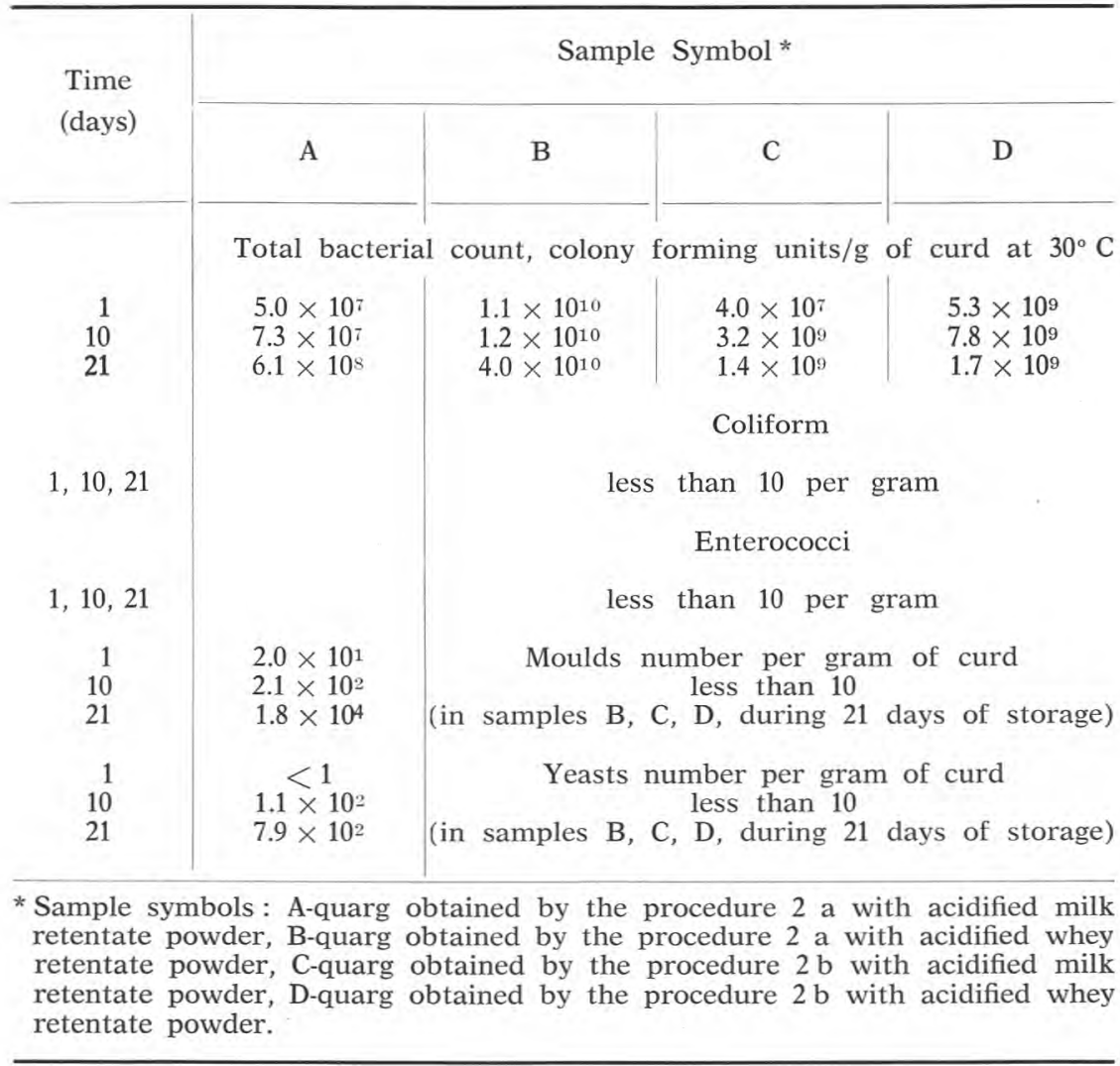

few hours lasting fermentation at $18-25^{\circ} \mathrm{C}$ before cooling improves the organoleptic quality of quarg.

The method described here gives the opportunity of creation of a large variety of fresh dairy products. We have chosen quarg as an example, but it could be any fermented milk food, as for example yoghurt type products or semi hard acid cheese type tvarog. We used milk and fermented milk as solvents of neutral and acid milk or whey permeate powders. It could be water or fruit juice as well. Special attention has to be stress on using over-acidified whey retentate powder as an acidifying agent, as whey protein has higher nutritive value than casein, but also as if gives smoother texture than over-acidified milk retentate powder. Infant formulas of whey- 
milk-fruit quargs or drinks in powder could be elaborated. We used L. acidophilus strain $1 \mathrm{~T}$ which acidifies milk to $\mathrm{pH} 3.1-3.2$ and milk retentate to $\mathrm{pH} 3.5$.

Similar results we have obtained with few strains of L. helveticus and $L$. bulgaricus, finaly we have chosen. $L$. acidophilus $1 T$ because it produced no flavour at all and gave the best texture. L. bulgaricus for example gave yoghurt like flavour, which is not acceptable in the case of quarg type products. Two strains of $L$. helveticus we have tried, gave glue like texture, not acceptable for quarg, but eventually acceptable for yoghurt type products.

If taking into account export products, the mixture of spray dried powders of neutral and acid milk or whey retentates together with spray dried or lyophilised flavour rich starter, eventually enriched with fruit flavours, could be a good composition for a "semi-product" to be regenerated in water or milk at home or in a dairy factory.

\section{References}

A.O.A.C. (1975), - Official Methods of Analysis of the Association of Official Analytical Chemist. Ed. W. Hornits. A.O.A.C. Washington, 1975, pp. 256, $282-4$.

Brulé (G.), Maubois (J.-L.), Fauquant (J.) (1974). - Etude de la teneur en éléments minéraux des produits obtenus lors de l'ultrafiltration du lait sur membrane. Lait, 539-540, 600-615.

Brulê (G.), Maubois (J. L.), Vandeweghe (J.), Fauquant (J.), Goudedranche (H.) (1975). - Utilisation de l'ultrafiltration sur membrane pour la fabrication de fromages du type pâtes frâiches. Revue Laitière Française, 328, 117-122.

Covacevich (R. H.) and KosikowsKi (F.V.) (1978 a). - Cottage cheese by ultrafiltration. Journal of Dairy Science, 61, 529-535.

Covacevivi (R. H.) and Kosikowski (F.V.) (1978 b). - Mozzarella and Cheddar cheese manufacture by ultrafiltration principles. Journal of Dairy Science, 61, 701-709.

Ehsani (R.), Bennasar (M.), Torodo de la Fuente (B.) (1982). - Aptitude à la coagulation de poudres de lait préacidifiés à $0^{\circ} \mathrm{C}$. Lait, 62, 276-300.

FIL-IDF (1971 a). - Laits fermentés: dénombrement des coliformes. Norme $\mathrm{n}^{\circ} 65$.

FIL-IDF (1971 b). - Laits fermentés : dénombrement des organismes microbiens de contamination. Norme $\mathrm{n}^{\circ} 66$.

FIL-IDF (1974 a). - Détermination de la teneur en lactose du lait. Norme $\mathrm{n}^{\circ} 28 \mathrm{~A}$.

FIL-IDF (1974 b). - Lait et produits laitiers: dénombrement des bactéries coliformes. Norme $\mathrm{n}^{\circ} 73$.

FIL-IDF (1980). - Lait et produits laitiers : levures et moisissures. Norme $\mathrm{n}^{\circ} 94$.

FIL-IDF (1981 a). - Examen sensoriel du lait et des produits laitiers. Norme $\mathrm{n}^{\circ} 99$.

FRIIS (T.) (1981). - Production of quarg by membrane filtration. North European Dairy Journal, 47 (6), 165-170.

Gungerich (C.) (1981). - Production of quarg by ultrafiltration. North European Dairy Journal, 47 (7), 212-217. 
HARWALKAR (V.R.) (1980). - Measurement of thermal denaturation of B-lactoglobulin at pH 2.5. Journal of Dairy Science, 63, 1043-1051.

KorolczuK (J.), GRZelaK (D.), ZMARLicki (S.), JaNicki (A.) (1983). - New approach to acid curd cheese technology. New Zealand Journal of Dairy Science and Technology, 18, 101-107.

KorolczuK (J.), GrzelaK (D.) (1984), - Acid curd cheese by MMV method with Lactobacillus acidophilus. Lait, 64, 1-15.

Mahaut (M.), Maubois (J.L.), Zink (A.) (1982). - Eléments de fabrication de fromages frais par ultrafiltration sur membrane de coagulum de lait. La Technique Laitière, 961, 9-13.

Maubois (J. L.), Mahaut (M.) (1974). - Application de l'ultrafiltration sur membrane dans l'industrie fromagère. Revue Laitière Française, 322, 479-484.

Maubois (J. L.), Mocouot (G.) (1971). - Préparation de fromage à partir de "pré-fromage liquide » obtenu par ultrafiltration du lait. Lait, 508, 495-533.

Maubois (J.L.), Mocouot (G.) (1975). - Application of membrane ultrafiltration to preparation of various types of cheese. Journal of Dairy Science, 58, 1001-1007.

Maubois (J.L.), Mocouot (G.), Vassal (L.) (1969). - Procédé de traitement du lait et des sous-produits laitiers. Brevet français, $\mathrm{n}^{\circ} 205121$.

Puhan (Z.), Gallmann (P.) (1981). - Ultrafiltration in the manufacture of quarg. North European Dairy Journal, 47 (1) 4-5.

Stenne (P.) (1973). - Procédé de fabrication d'aliments protéiques, notamment de fromages. Brevet français, $\mathrm{n}^{\circ} 2232999$. 